\title{
Dr. R. E. Bradbury: Index and Listing of Manuscript Field Work Records
}

THE late Dr. R. E. Bradbury spent the major part of a decade undertaking anthropological studies of the Edo and neighbouring peoples of Nigeria, and left a large quantity of manuscript material dealing, particularly, with history and political organization, art, ritual, and ceremonies. A grant from the Association of Social Anthropologists, U.K., has enabled these records to be ordered, filed, listed, and indexed by Mrs. M. Fraenkel. They have now been lodged with the Centre for West African Studies at the University of Birmingham, where Dr. Bradbury was teaching at the time of his death. A copy of the index and lists is also available at the University of Ibadan, Nigeria, where enquiries should be addressed to Professor A. C. Ryder at the Department of History.

\section{'African Studies': Fiftieth Anniversary Number: Essays Presented to Clement $M$. Doke}

True fiftieth number of African Studies (vol. xxx, nos. 3-4, 1971) takes the form of a tribute to Dr. Clement M. Doke, Professor Emeritus of Bantu Languages at the Witwatersrand University. The first volume of the journal (then called Bantu Studies) was published in I92 I under the editorship of Mr. J. D. Rheinallt Jones. Professor Doke became a joint editor with him in $193 \mathrm{I}$ and continued in this capacity until his retirement from the University of Witwatersrand at the end of 1953 . The papers presented to Professor Doke have been contributed by Desmond T. Cole, A. T. Cope, G. Fortune, Lyndon Harries, M. D. W. Jeffreys, L. W. Lanham, C. L. S. Nyembezi, A. N. Tucker, N. J. van Warmelo, and D. Ziervogel. The number also contains a bibliography of Professor Doke's published and unpublished works from 1913 to 1970 .

\section{Academic Theses on Ghana, I920-70}

MR. J. K. T. Kafe, Assistant Librarian at the Balme Library, University of Ghana (P.O. Box 24, Legon), has compiled an annotated bibliography of academic theses on Ghana and has listed approximately 550 titles and 60 institutions. The work is in two parts, the first listing titles broadly by subject, and the second giving a chronological country arrangement by names of institutions. An Appendix lists related titles under various headings such as British Empire and Commonwealth, Developing Nations, Africa, Slavery, and West Africa.

\section{'Djénné: Une Cité Soudanaise', by Charles Monteil}

THIs study, one of the Institute's earliest publications, is now available again, after being out of print for many years, in a reprint by Editions Anthropos, Paris, with a Preface by the author's son, Professor Vincent Monteil. Djerné was originally published in 1932 through the efforts of Professor Henri Labouret, one of the Institute's first Directors. The new edition contains some additional illustrations, photographs taken in 1902 by the author of his original informants, the chief scholars and marabouts in Djénné. The price of the reprint is Frs. $37.20, £^{2} \cdot 80$ (obtainable by Members from the Institute).

\section{Back Issues of 'Africa'}

BACK issues of Africa, vols. i-xl (1928-70) inclusive, are obtainable from Wm. Dawson and Sons Ltd., Cannon House, Folkestone, Kent, England. Back issues are also available on microfilm, for which orders and enquiries should be sent direct to Micro Methods Ltd., East Ardsley, Wakefield, Yorks., England. 